\title{
AYURLOG
}

National Journal of Research in Ayurved Science

A peer-reviewed open access Indexed e-journal of Ayurved

http://www.ayurlog.com

April- 2020 | Volume 08 ${ }^{\text {th }}$ | Issue: $2^{\text {nd }}$

ISSN: 2320-7329

\section{Novel corona Virus (2019-nCoV) - An Ancient Ayurveda \\ Epidemiology Literature Review.}

Gangaprasad Anantrao Waghmare (MS, PGDCS, PhD Scholar)

Asst. Professor, KGMPA College \& Hospital, Mumbai-02

Abstract:

Corona viruses are a large family of viruses that cause illness ranging from the common cold to more severe diseases such as Middle East Respiratory Syndrome (MERS-CoV) and Severe

Acute

Respiratory Syndrome (SARS-CoV). In more severe cases, infection can cause pneumonia, severe acute respiratory syndrome, kidney failure and even death Initially, the World Health Organization (WHO) had mentioned $2 \%$ as a mortality rate estimate in a press conference on Wednesday, January 29 and again on February 10. However, on January 292020 WHO specified that this was a very early and provisional estimate that might have changed. 3.4\% Mortality Rate estimate by the World Health Organization (WHO) as of March 3 2020. The concept of epidemic was very much well defined in Ayurveda, Acharya Charaka the great physician of all ages had mentioned the epidemic diseases under the heading of “Janapadodhwans". The aim of this review study is to understand the ancient Ayurveda epidemic literature, to prevent people from getting affected by epidemic diseases and to enlighten on epidemic diseases prevention \& Management through Ayurveda.

Keywords: Novel corona Virus (2019$\mathrm{nCoV})$, severe acute respiratory syndrome,Janapadodhwans, Ayurveda, epidemic Diseases, communicable disease, Panchakarma, Rasayan.

\section{Introduction:}

Corona viruses $(\mathrm{CoV})$ are a large family of viruses that cause illness ranging from the common cold to more severe diseases such as Middle East Respiratory Syndrome (MERS-CoV) and Severe Acute Respiratory Syndrome (SARS-CoV) is a new strain that has not been previously identified in humans. Corona viruses are zoonotic, meaning they are transmitted between animals and people.Common signs of infection include respiratory symptoms, fever, cough, shortness of breath and breathing difficulties. In more 
severe cases, infection can cause pneumonia, severe acute respiratory syndrome, kidney failure and even death.

India, being a third-world country, has encountered a variety of epidemics and pandemics through time. Epidemics is an unusual occurrence in a community or region of disease, specific health-related behavior or other health-related events clearly in excess of expected occurrence. It is a sudden, severe widespread outbreak of a disease pre-existing in the community. These are the global health problems that need to be addressed and treated viciously along with proper measures to avoid transmission to other countries.

Ayurveda describes a concept called "Janapadodhwans" that can approximately be compared with epidemic and its several variants based on the degree and intensity of the event.

Terms used by Acharyas for Epidemic:

\begin{tabular}{|l|l|l|}
\hline $\begin{array}{l}\text { Sr. } \\
\text { No. }\end{array}$ & Acharya & $\begin{array}{l}\text { Epidemic } \\
\text { Synonym }\end{array}$ \\
\hline 1 & Charaka & Janapadodhwans \\
\hline 2 & Sushruta & Marak \\
\hline 3 & Bhel & Janamaar \\
\hline
\end{tabular}

The birth of Janapadodhwans term came by Query lead by Agnivesha to Acharya Atreya, that "People having dissimilar nature, diet, physical strength, homologation, mental faculties \& age, simultaneously get affected by the same epidemic disease".

Even though there is dissimilarities in the physical constitution still there are some factors as are common to all individual, they are Vayu (Air), Jala (Water), Desh (Land), and Kala (Season). Janapadodhwans occurs due to vitiation of Vayu (Air), Jala (Water), Desh (Land), and Kala (Season). Charaka has dedicated Chapter on Epidemic disorders ,that is "Janapadodhwans Vimaniyam".

\section{Characteristics of Vitiated Air:}

1. Absence of Characteristic feature in conformity with season.

2. Excessive calmness or violent blow.

3. Excessive dryness, cold ,heat, humidity.

4. Excessively Cyclonic in Nature.

\section{Characteristics of Vitiated Water:}

1. Excessive abnormality in smell, colour, taste \& touch.

2. Excessive Stickiness.

3. Absence of bird that move on water.

4. Reduction in number of Aquatic animals.

\section{Characteristics of Vitiated Land:}

1. Abnormality in the natural colour, smell, taste \& touch.

2. Abundance of serpents, wild animals 
,mosquitoes,locusts,flies,rats,owls, vultures \& jackals.

3. Having jungles of grass \& weeds.

4. Abundance of excessively branched creepers.

5. Presence of wild cries of birds \& dogs.

6. Frequent occurrence of meteorites, thunderbolts \& earth quakes.

7. Constant agitation \& overflow of water reservoirs. Etc

\section{Characteristics of Vitiated Season :}

Manifestation of the characteristic features contrary to the normal conditions of the various seasons is consider to be harmful.

Vitiation of water, land \& season are more harmful than those of air, water \& land respectively.

While Ayurveda summarizes all the relevant concepts in one word as Janapadodhwansa Rogas, modern medicine describes several terminologies to explain the degree and intensity of such events that include outbreak, epidemic, pandemic, and endemic.

\section{Classification of Diseases:}

Acharya Sushrut, one of the proponents of Ayurveda, has classified diseases into three major categories in his classical treatise, Sushrut Samhita. These are Adhyatmika, Adhibhoutik, and Adhidaibik.

\begin{tabular}{|l|l|l|}
\hline $\begin{array}{l}\text { Sr. } \\
\text { No. }\end{array}$ & $\begin{array}{l}\text { Concept in } \\
\text { Ayurveda }\end{array}$ & $\begin{array}{l}\text { English Equivalent of } \\
\text { Ayurvedic Concept }\end{array}$ \\
\hline 1 & Adhyatmika & $\begin{array}{l}\text { Psychosomatic Disorders } \\
\text { 1. Congenital Anomalies } \\
\text { 2. Hereditary Disorders } \\
\text { 3. Humoral, intestinal \& } \\
\text { Psychic }\end{array}$ \\
\hline 2 & Adhibhoutik & $\begin{array}{l}\text { Traumatic } \\
\text { 1. Due to arms \& } \\
\text { Weapons } \\
\text { 2. Due to Animals }\end{array}$ \\
\hline 3 & Adhidaibik & $\begin{array}{l}\text { Natural } \\
\text { 1. Seasonal } \\
\text { 2. Supernatural agencies } \\
\text { 3. Functional }\end{array}$ \\
\hline
\end{tabular}

Etiology of Epidemic in Ayurveda :

According to Ayurveda there are mainly three routes of Cause of all Diseases.

1. Pragyaparadha: Mistake of Intellect.

2. AsatmedriyarthaSamyoga:

Improper Contact of senses with their objects, results in over stimulation \& deficiency of sensory activity

3. Parinaam or Kala: The external environment can trigger disease by unbalancing the body through unnatural \& extreme variations in temperature , Rainfall or wind which in turn leads to causation of epidemics. 
Modes of communicable disease transmission:

Acharya Sushrut, one of the proponents of Ayurveda, has depicted different modes of communicable disease transmission in his classical treatise Sushrut Samhita. He says by physical contact (Gātrasansparśāt), expired air (Nihśviāsāt), eating with others in same plate (Saha bhōjanāta), sharing a bed (Sahaśayyāsanāccāpi), using clothes, garlands, and paste (Vastamālyānulēpanāt) infectious diseases spread from person to person. These concepts are very much relevant today. Moreover, the modern texts of communicable disease epidemiology describe similar modes of disease transmission.

\section{Management:}

Ayurveda propounds an equally comprehensive four dimensional concept of Swasthya or health. In this context the individual factors such as prakriti (psychosomatic constitution), sattva (mental status), vayas (age), bala (strength), agni (digestion \& metabolism), ojas (immunity) etc. are to be considered. Similarly, the impact of external factors such as desa (habitat), kala (seasons), vayu (environment), udaka (water), etc. have been emphasized. Ayurvedic texts describe a comprehensive list of health regimen for preservation of health popularly known as svasthavritta. This includes dinacarya (daily code of health conduct), Rutucarya (seasonal code of health conduct) etc. Details about life-style, diet, physical exercise, personal discipline and social hygiene (Sadvritta) have been described.

Ayurveda also describes in detail the role of periodical biological cleansing known as panchakarma and consumption of restorative remedies such as rasayana for promotion of health, longevity immunity. As per Ayurveda principles, diseases are caused due to an imbalance in the tridosha due to various factors.

\section{A) Prevention :}

1. Practice daily regimen and seasonal regimen especially oral hygiene, nasya karma (nasal administration of medicament) and dhumapana (medicated smoking)

2. Consume wholesome, compatible and easily digestible food,

3. Avoid the causative factors like exposure to cold weather, pollutants, pollen grains, etc.

4. Avoid kapha aggravating and allergic food.

\section{Pathya Apathya}

a) Should consume:

1. Daily inhalation with medicated steam.

2. Ghee after food (uttara bhaktika sarpi)

3. Low calorie diet, easily digestible food, raw fruits 
4. Old rice (Sali), garlic (rasona), drum stick (Shigru), patola

5. Light, sour, salty, unctuous diet

b) Should avoid:

1. Fried and frozen food, allergic food

2. Perfumes, strong odours

3. Exposure to breeze/ cold/ damp weather

4. Drinking chilled water

5. Head Bath with cold water

6. Suppression of natural urges

7. Day sleep

\section{B) Ayurvedic Medicinal Management:}

1. Nidana parivarjana: Avoid the precipitating factors whenever possible, consume compatible diet and adopt life style modifications suitable to the disease condition.

Following Ayurvedic medicinal treatment may be used as per dosh-dush status and as per samprapti developed:

2. Samshodhana chikitsa (Detoxification):

I. Single Drug:
- Snehana (Oil Massage)

- Svedana ( Body Steam)

- Vamana (Emesis)

- Kaya virecana (Purgative)

- Shiro virecana (navana) with kshira sarpi

- Shadbindu taila or apamarga svarasa nasya

- Pradhamana nasya wth katphala churna or vacha.( nasal administration of medicament)

- Asthapana Basti (Enema)

- Raktamokhanal siravedhana (Blood Letting)

3. Other procedural therapies

- Dhumapana (Herbal Smoking)

- Gandusha dharana

- Kavalagraha (Gargling)

- Shirobasti

4. Shamana Chikitsa (Drug therapy)

\begin{tabular}{|c|c|c|c|c|}
\hline $\begin{array}{l}\text { Sr. } \\
\text { No. }\end{array}$ & Drug & Daily Dose & $\begin{array}{l}\text { Compliant } \\
\text { Anupana }\end{array}$ & Duration \\
\hline 1 & $\begin{array}{l}\text { Ardraka (Zingiber } \\
\text { officinale) }\end{array}$ & $5 \mathrm{gm} \mathrm{BD}$ & $\begin{array}{l}\text { Fry in Cow's } \\
\text { Clarified Butter }\end{array}$ & 15 Days \\
\hline 2 & $\begin{array}{ll}\text { Vibhitaki } & \text { (Terminalia } \\
\text { bellerica ) } & \end{array}$ & $3 \mathrm{gm} \mathrm{BD}$ & Water & 15 Days \\
\hline 3 & Maricha (Piper nigrum) & $2 \mathrm{gm} \mathrm{BD}$ & Jaggery & 15 Days \\
\hline
\end{tabular}


II. Compound formulations :

\begin{tabular}{|c|c|c|c|c|}
\hline $\begin{array}{l}\text { Sr. } \\
\text { No. }\end{array}$ & Drugs & Daily Dose & $\begin{array}{l}\text { Mode of } \\
\text { Action/Compliant }\end{array}$ & Duration \\
\hline 1 & Anu Taila & $\begin{array}{l}6 \text { drops in each } \\
\text { nostril Twice daily }\end{array}$ & $\begin{array}{l}\text { Nasal } \\
\text { Administration }\end{array}$ & 15 Days \\
\hline 2 & $\begin{array}{l}\text { Chitraka Haritaki } \\
\text { Avaleha }\end{array}$ & 6-12 gm BD & Warm Water & 15 Days \\
\hline 3 & $\begin{array}{l}\text { Nardiya Lakshmi vilasa } \\
\text { Rasa }\end{array}$ & $250 \mathrm{mg} \mathrm{BD}$ & Honey & 15 Days \\
\hline 4 & $\begin{array}{l}\text { Panchatikta Guggulu } \\
\text { Ghruta }\end{array}$ & 6-12 ml BD & Warm Water & 15 Days \\
\hline 5 & Pathyadi Kwath & $10-20 \mathrm{ml} \mathrm{BD}$ & Warm Water & 15 Days \\
\hline 6 & Vyoshadi Vati & 500mg TDS/QID & Warm Water & 15 Days \\
\hline 7 & Mahasudarshana Vati & 500mg TDS/QID & Warm Water & 15 Days \\
\hline 8 & Suvarna Vasant Malati & $250 \mathrm{mg} \mathrm{BD}$ & Warm Water & 15 Days \\
\hline 9 & Pippali Rasayan & $\begin{array}{l}250 \mathrm{mg} \text { Tapering } \\
\text { dose }\end{array}$ & Warm Water & 15 Days \\
\hline 10 & Shwasa Kuthar rasa & $250 \mathrm{mg} \mathrm{BD} / \mathrm{TDS}$ & Warm Water & 15 Days \\
\hline
\end{tabular}

1) Rasayan Therapy (Rejuvenation):

Rasayana therapy (Rejuvenation) has been described in Ayurveda as a systematic and scientific medical discipline. According to Acharya Charak, the substance which invigorate a healthy person by producing the best quality of Rasa, Rakta dhatu and other dhatus (Basic element of body) are called as Rasayana. Rasayana aid in increasing natural immunity, enhancing general well-being, improving the functioning of all fundamental organs of the body and keep the signs of early aging at bay.

It basically boosts the Oja (vital force of life) and the immune system. Most of these Rasayana can be used regularly as a food for maintaining balanced mental and physical health.

\section{Classification of Rasayana:}

As per contents of Rasayana-

1. Aushadha Rasayana - Based on drugs and herbs

2. Ahara Rasayana - Based on diet and nutrition 
3. Achara Rasayana - Based on conduct and behaviour (Practice daily regimen and seasonal regimen)

\section{Conclusion:}

The world is facing to Epidemic diseases since from Ancient time. Literature related to Epidemic diseases their Causation, Prevention \& Management is timely mentioned in Ancient Indian literature like Atharveda , Upanishada, vedas etc. Ayurveda has clearly mentioned detail study of Krimivignyan (Micro-organism) which are responsible as causative agent for diseases. Ayurveda has mentioned importance of daily adopting swasthyayoga, Dincharya $\&$ Rutucharya (Practice daily regimen and seasonal regimen) in life to prevent mankind from getting infected from community diseases.

As per Ayurveda principles, all diseases are caused due to an imbalance in the tridosha (Vata, pitta \& Kapha) due to various factors. So therapeutic management (Oral medication \& Panchakarma) are done to break pathology which create imbalance of this tridosha. Also Rasayan therapy helps in building Saptadhatu (basic elements of body) \& keeping Longevity.

So we can conclude that epidemic diseases are formerly explained in details in ancient Ayurveda literature with their prevention \& management. We can use this knowledge as basic principle with up gradation as per current scenario for better well being.

\section{References:}

1. Venimadhavshastri Joshi, Narayan Hari Joshi, Ayurvediya Shabdakosha Maharashtra Rajya sahitya \& Sanskruti Mandal, Mumbai, 1968.

2. Brahmanand Tripathi,Charak Samhita- Agnivesha, Chaukhambha Sanskrit Sansthan, Varanasi, 1983.

3. DrRam karan Sharma \& Vd Bhagwan

Dash;

janapadhwansaniya

vimana;Charak

Samhita;

Chowkhamba Sanskrita Sansthan varanasi; $5^{\text {th }}$ edition 1998.

4. Kaviraj Dr. Ambikadatta Shastri Sushrut Samhita- Sushrut Chaukhambha Sanskrit Sansthan, Varanasi-221001, 1989.

5. Harsh mohan, Textbook Of Pathology, $7^{\text {th }}$ Edition ,Jaypee Publication.

6. Yadavaji Trikamji Acharya, Dalhan, Nibandha Sangraha comm.(1994) on Sushruta,

Chaukhambha Sanskrit Sansthan, Varanasi, India.

7. Kaviraj Ambikadatta Shastri Vidyotini Hindi Comm (1970) Edited by shri Rajeshwar Datta 
Shastri Bhaishajya Ratnavali

Choukhambha Sanskrit Sansthan, Varanasi, India.

8. 8. Yadavjitrikamjiaachrya, Ayurned Deepika (1941) Chakrapani data comm. on -Charak Samhita, Nirnaya Sagar Press, Mumbai, India.

9. Indian Materia Medica- By A.K.Nadkami, Popular Book Depo, Mumbai, 1956.

10. Acharya Priyawat Sharma, Dravya Guna Vignyana, Published By Chaukhambha Bharti Acadamy, Varanasi, India.
11. Vd. Girijadayalu Shukla, Janapadavibhaktiya Adhyaya;Bhel Samhita ,Published By Chaukhambha Bharti Acadamy, Varanasi, India.

12. Atlanta, Georgia; Principles of epidemiology, centres for disease control \& prevention, $2^{\text {nd }}$ edition

13. K. Park Textbook of preventive \& social medicine $; 23^{\text {rd }}$ edition, Bhanot publication .

14. https://www.who.int/emergencies/d iseases/novel-coronavirus-2019

15. https://www.worldometers.info/cor onavirus/coronavirus-death-rate

\section{Cite this article:}

"Novel corona Virus (2019-nCoV) - An Ancient Ayurveda Epidemiology Literature Review." Gangaprasad Anantrao Waghmare 